\title{
GMR
}

\section{Early selection of sugarcane using path analysis}

\author{
R.P. Barbosa ${ }^{1}$, F. Alcântara Neto ${ }^{1}$, L.M. Gravina ${ }^{2}$, G.A. Gravina ${ }^{2}$, \\ M.G.T. Portela ${ }^{1}$ and A.A.C. Bezerra ${ }^{3}$ \\ ${ }^{1}$ Departamento de Fitotecnia, Universidade Federal do Piauí, Teresina, PI, Brasil \\ ${ }^{2}$ Laboratório de Engenharia Agrícola, \\ Universidade Estadual do Norte Fluminense Darcy Ribeiro, \\ Centro de Ciências e Tecnologias Agropecuárias, Campos dos Goytacazes, \\ RJ, Brasil \\ ${ }^{3}$ Departamento de Planejamento e Política Agrícola, \\ Universidade Federal do Piauí, Teresina, PI, Brasil \\ Corresponding author: G.A. Gravina \\ E-mail: gravina@uenf.br \\ Genet. Mol. Res. 16 (1): gmr16019038 \\ Received July 28, 2016 \\ Accepted December 12, 2016 \\ Published February 8, 2017 \\ DOI http://dx.doi.org/10.4238/gmr16019038
}

Copyright $\left({ }^{\circ} 2017\right.$ The Authors. This is an open-access article distributed under the terms of the Creative Commons Attribution ShareAlike (CC BY-SA) 4.0 License.

\begin{abstract}
The aim of this study was to analyze sugarcane (Saccharum officinarum) biometric and technological data, obtained at different timepoints, using path analysis. The experiment was conducted in União, PI, Brazil, and evaluated 12 sugarcane genotypes (RB036066, RB9438, RB935744, RB021764, RB021754, RB021534, RB966229, RB977540, RB863129, and RB987935, and the varieties RB92579 and RB867515 as controls) in a randomized block design with four replications. Data were collected at six timepoints that were spaced 30 days apart (90, 120, 150, 180, 210, and 240 days). Direct and indirect effects of the following production components were compared: stalk length, stalk diameter, internode length, number of tillers, number of green leaves, and stalk dry matter. The technological variables evaluated were total recoverable sugar, degrees Brix, tons of polarization (pol, apparent sucrose content) per hectare, juice purity, fiber, juice pol, and tons of sugarcane per hectare. The coefficients of determination were
\end{abstract}

Genetics and Molecular Research 16 (1): gmr16019038 
high in all path analyses, suggesting that the components evaluated explained a large part of the variation in stalk production and in the technological variables. Stalk diameter was the trait that best correlated with stalk dry matter yield at all timepoints, with positive values that were higher than the residual effect. This demonstrates the possibility of obtaining significant gains via indirect selection for stalk dry matter yield via stalk diameter or via stalk diameter and number of tillers. The technological variables degrees brix and juice pol were the traits that best correlated with total recoverable sugar production, indicating that they could be used to indirectly select for total recoverable sugar.

Key words: Saccharum officinarum L.; Relationship between traits; Indirect selection

\section{INTRODUCTION}

The study of relationships between variables is necessary to measure the existence and/or intensity of interactions between traits. In general, these relationships are evaluated through correlations that, in plant breeding for instance, are important, because correlations between traits allow for selection based on a single trait to result in simultaneous changes in one or more characters of agronomic importance. Consequently, many breeding programs use correlations. Correlation analysis allows the breeder to evaluate the degree of association between two traits and the practical viability of indirect selection, which, in some cases, may lead to more rapid progress than direct selection (Cruz et al., 2006; Ferreira et al., 2007).

The correlations evaluated in plant breeding can be of a phenotypic, genotypic, or environmental nature. Phenotypic correlations have genetic and environmental causes, but only genetic causes are heritable and used in breeding programs (Cruz et al., 2004; Esposito et al., 2012). However, despite being an easily obtained statistical parameter, the magnitude of a correlation must be interpreted carefully, because this process is complicated by its significance, the importance of the traits, the effect of two or more traits, and the influence of the environment on their expression (Falconer and Mackay, 1996).

Path analysis can distinguish between the direct and indirect effects of variables that influence a basic or main variable of greater interest (Cruz et al., 2006). The technique, introduced by Wright $(1921,1923)$ and described in detail by Li $(1956,1975)$, identifies miscorrelations between two traits that may not necessarily be related by direct cause-andeffect, because of the influence of a third trait. Path analysis has been widely used by plant breeders in a variety of crops, e.g., soybean (Peter et al., 2014), corn (Faria et al., 2015), common bean (Cabral et al., 2011), green bean (Araujo et al., 2012), cowpea (Moura et al., 2012; Santos et al., 2014), rice (Marchezan et al., 2005), wheat (Kavalco et al., 2014), cotton (Hoogerheide et al., 2007; Farias et al., 2016), sweet sorghum (Lombardi et al., 2015), and sugarcane (Saccharum officinarum) (Kang et al., 1983; Reddy and Reddy, 1986; Sukhchain and Sain, 1997; Ferreira et al., 2007; Silva et al., 2009; Souza et al., 2011; Esposito et al., 2012). However, studies of this nature are still necessary, because different population structures, environments, and management strategies should be considered.

The current study evaluated different genotypes at different timepoints and the genetic consequences of relationship between traits. Our results will facilitate the manipulation of

Genetics and Molecular Research 16 (1): gmr16019038 
these genotypes and indicate their most suitable traits, which would be indispensable when performing indirect selection on sugarcane because it reduces the amount of work necessary when assessing a large number of genotypes in the initial stages of a breeding program.

In view of the above considerations, and given the need for honing the process of selection of promising genotypes in sugarcane breeding programs, the present study was conducted to quantify, by path analysis, the direct and indirect effects of production components on the yield of stalks per hectare, and of technological variables on the total recoverable sugar (TRS) at six data collection periods.

\section{MATERIAL AND METHODS}

The experiment was conducted on June 7, 2013, at Companhia Vale do Parnaíba alcohol and sugar mill that belongs to the Olho D'água group, which is in União, PI, Brazil $\left(04^{\circ} 52^{\prime} 09^{\prime \prime} \mathrm{S}, 42^{\circ} 52^{\prime} 45^{\prime \prime} \mathrm{W}, 67 \mathrm{~m}\right.$ above mean sea level). According to Thornthwaite and Mather (1955), the climate of the region is classified as dry sub-humid, with a moderate water surplus in the summer and a water shortage from July to December.

A randomized block design with four replications was adopted, and included 12 sugarcane genotypes (RB036066, RB9438, RB935744, RB021764, RB021754, RB021534, RB966229, RB977540, RB863129, and RB987935, and the varieties RB92579 and RB867515 as controls) obtained from the sugarcane breeding programs of the Inter-University Network for the Development of Sugar and Alcohol Sector (Rede Interuniversitária para o Desenvolvimento do Setor Sucroalcooleiro, RIDESA).

The plot was composed of two 5-m furrows spaced $1.4 \mathrm{~m}$ apart. Each linear meter of furrow received six sugarcane cuttings with three buds each (totaling 18 buds per linear meter). Base fertilization was based on a chemical analysis of the soil (Table 1), and consisted of $500 \mathrm{~kg}$ / ha of 06-28-22 (N, P and K, respectively) formulation that was applied in the planting furrow.

Table 1. Chemical characteristics of the soil in the experimental area.

\begin{tabular}{|c|c|c|c|c|c|c|c|c|c|}
\hline \multirow[t]{2}{*}{ Depth (m) } & \multirow[t]{2}{*}{$\mathrm{pH}\left(\mathrm{CaCl}_{2}\right)$} & P (Mehlich) & $\mathrm{K}$ & $\mathrm{Ca}$ & $\mathrm{Mg}$ & $\mathrm{Al}$ & $\mathrm{H}+\mathrm{Al}$ & AlS & $\mathrm{BS}$ \\
\hline & & \multicolumn{2}{|c|}{$\mathrm{mg} / \mathrm{dm}^{3}$} & \multicolumn{3}{|c|}{$\mathrm{Cmol}_{\mathrm{d}} / \mathrm{dm}^{3}$} & \multicolumn{3}{|c|}{$\%$} \\
\hline $0.00-0.20$ & 7.0 & 94.3 & 0.59 & 2.14 & 0.99 & 0.0 & 0.47 & 0.0 & 88.80 \\
\hline $0.20-0.40$ & 7.0 & 100.2 & 0.53 & 2.34 & 0.86 & 0.0 & 0.49 & 0.0 & 88.30 \\
\hline $0.40-0.60$ & 6.9 & 100.3 & 0.52 & 2.39 & 0.84 & 0.0 & 0.50 & 0.0 & 88.20 \\
\hline
\end{tabular}

$\mathrm{BS}$, base saturation; A1S, aluminum saturation.

The following traits were evaluated from September 2013 to February 2014: stalk length (SL) in meters, which was the distance from the base of the stalk to the first visible leaf, and obtained by randomly sampling stalks from each tussock; stalk diameter (SD) in mm, which was measured at the fifth internode from the base of the stalk to the apex, measured with a caliper on a randomly sampled stalk from each tussock; internode length (IL), which was measured with a graduated ruler at the same internode as where the SD was obtained; the number of tillers (NT), which was obtained by counting the number of tillers on each tussock in the usable area of the plot; the number of green leaves (NGL), which was obtained by counting the number of green leaves on each plant that had been selected to measure the SD; and stalk dry matter (SDM), which was the total mass of the plot (stalks without leaves, cut close to the soil). The technological variables evaluated were TRS, degrees Brix (Brix), tons of pol (apparent sucrose content) per hectare (TPH), juice purity, fiber, juice pol, and tons of sugarcane per hectare.

Genetics and Molecular Research 16 (1): gmr16019038 
Initially, analysis of variance was performed for each environment (collection time) separately, and the homogeneity of the residual variance was checked. Later, a combined analysis of variance was performed that included progeny and environment as random terms, and subsequently, genotypic and phenotypic correlations were estimated.

The degree of multicollinearity of a $X^{\prime} X$ correlation matrix was established based on its condition number $(\mathrm{CN})$, which is the ratio between the highest and lowest eigenvalue of the matrix (Montgomery and Peck, 1981) and indicates weak multicollinearity between explanatory variables if the ratio between the highest and lowest eigenvalue is equal to or lower than 100. If the $\mathrm{CN}$ is $100-1000$, multicollinearity is considered moderate to severe, and if $\mathrm{CN} \geq 1000$, it is considered severe (Moura et al., 2012).

After the establishment of the basic path analysis equations, the resolution in matrix form was obtained according to the equation $\mathrm{X}^{\prime} \mathrm{X} \beta=\mathrm{X}^{\prime} \mathrm{Y}$, where $\mathrm{X}^{\prime} \mathrm{X}$ is a nonsingular matrix of correlations between the primary variables, $\beta$ is the path coefficient vector column, and $\mathrm{X}^{\prime} \mathrm{Y}$ is the column vector of correlations between the explanatory variables and the dependent variable (Santos et al., 2014).

The following conditions were considered for the path analysis: i) SDM was the main variable and the production variables (NGL, NT, SL, IL, and SD) were explanatory variables; ii) TRS was the main variable and the technological variables [Brix, fiber, purity, juice pol, reducing sugar (RS), TPH, and tons of sugarcane per hectare] were explanatory variables. All of the analyses were performed using the GENES software (http://www.ufv.br/dbg/genes/genes.htm).

\section{RESULTS AND DISCUSSION}

Preliminary analyses confirmed the normality of the data and homogeneity of the variance of the experimental error, allowing the inclusion of the six periods of evaluation in a combined analysis. Significant differences were found for all of the traits evaluated. Good experimental precision was observed for most traits, with coefficients of variation lower than $20 \%$. The $\mathrm{CN}$ values were lower than 100 , except at 120 days of age for the production variables, for which a path analysis under multicollinearity was performed. After this procedure, the highest variance inflation factor was 6.11, using a $\mathrm{K}$ value of 0.2069 . For the other periods evaluated, multicollinearity was classified as weak. Therefore, the path analyses were performed without the need for more complex statistical approaches. In addition, the high coefficients of determination of the path models (greater than 0.83 ) supported the use of this technique (Tables 2 and 3 ).

The genotypic correlations among the six independent variables and the dependent or main variable, as well as a decomposition of the genotypic correlations into components of direct and indirect effects on the dependent or main variable (SDM) and the independent explanatory variables for production traits, are described in Table 2 for each timepoint. The strongest genotypic correlations between the explanatory variables and the main variable were obtained for SD, IL, and SL at most of the timepoints. Considering only the correlation coefficients, SD, IL, and SL were the most important production components in the determination of SDM.

Among the explanatory variables, SD was the only trait that exhibited a strongly positive direct effect (greater than the residual effect) on SDM at all timepoints. The direct effect of SD on SDM was also higher than the indirect effect. SD explained most of the variation in the SDM yield.

Genetics and Molecular Research 16 (1): gmr16019038 
Table 2. Decomposition of genotypic correlations into components of direct and indirect effects involving the main dependent variable (stalk dry matter, SDM) and independent, production explanatory variables in 12 sugarcane genotypes at six timepoints.

\begin{tabular}{|c|c|c|c|c|c|c|}
\hline NT & $\begin{array}{l}\text { Estimate } \\
\text { (90 days) }\end{array}$ & $\begin{array}{c}\text { Estimate } \\
(120 \text { days })^{*}\end{array}$ & $\begin{array}{c}\text { Estimate } \\
\text { (150 days) }\end{array}$ & $\begin{array}{c}\text { Estimate } \\
\text { (180 days) }\end{array}$ & $\begin{array}{c}\text { Estimate } \\
\text { (210 days) }\end{array}$ & $\begin{array}{c}\text { Estimate } \\
\text { (240 days) }\end{array}$ \\
\hline Direct effect on SDM & 0.2739 & -0.0077 & 0.3732 & 1.0942 & 0.9114 & 0.2331 \\
\hline Indirect effect via NGL & -0.0051 & -0.0024 & -0.0711 & -0.1029 & 0.0042 & -0.0989 \\
\hline Indirect effect via IL & -0.1669 & -0.1395 & 0.2458 & -0.0268 & -0.0249 & 0.0220 \\
\hline Indirect effect via SL & -0.2297 & 0.0607 & 0.1017 & -0.4969 & 0.0120 & -0.1493 \\
\hline Indirect effect via SD & 0.2173 & -0.0812 & -0.2456 & -0.0068 & -0.0623 & 0.0323 \\
\hline Indirect effect via LDM & 0.0751 & 0.2421 & -0.1282 & -0.0129 & -0.2556 & 0.0254 \\
\hline Total & 0.1646 & 0.0704 & 0.4164 & 0.4477 & 0.5848 & 0.2049 \\
\hline \multicolumn{7}{|l|}{ NGL } \\
\hline Direct effect on SDM & -0.0155 & -0.0112 & 0.1529 & -0.3205 & 0.7099 & -0.1653 \\
\hline Indirect effect via NT & 0.0902 & -0.0016 & 0.1735 & 0.3512 & 0.0054 & 0.1394 \\
\hline Indirect effect via IL & -0.2034 & 0.0261 & 0.1348 & -0.0069 & -0.0838 & -0.0255 \\
\hline Indirect effect via SL & 0.2719 & 0.0576 & -0.0294 & 0.1466 & 0.0011 & -0.4515 \\
\hline Indirect effect via SD & 0.2176 & -0.0758 & -0.1452 & 0.0316 & -0.1048 & 0.2730 \\
\hline Indirect effect via LDM & -0.0402 & -0.0936 & -0.0294 & -0.0225 & 0.0097 & -0.0094 \\
\hline Total & 0.3205 & -0.1009 & 0.2572 & 0.1795 & 0.5375 & -0.3386 \\
\hline \multicolumn{7}{|l|}{ IL } \\
\hline Direct effect on SDM & -0.3870 & 0.3807 & -0.6522 & -0.2071 & -0.3346 & 0.1964 \\
\hline Indirect effect via NT & 0.1181 & -0.0028 & -0.1406 & 0.1419 & 0.0680 & 0.0261 \\
\hline Indirect effect via NGL & -0.0082 & -0.0007 & -0.0316 & -0.0107 & 0.1777 & 0.0215 \\
\hline Indirect effect via SL & 0.3214 & 0.1529 & -0.0899 & 0.2727 & 0.0009 & -0.1302 \\
\hline Indirect effect via SD & 0.8525 & 0.4250 & 0.4953 & 0.2980 & -0.0836 & 0.4437 \\
\hline Indirect effect via LDM & -0.0423 & -0.1974 & 0.2090 & 0.0187 & -0.0225 & 0.1006 \\
\hline Total & 0.8545 & 0.8420 & -0.2100 & 0.5135 & -0.1941 & 0.6861 \\
\hline \multicolumn{7}{|l|}{ SL } \\
\hline Direct effect on SDM & 1.1961 & 0.3608 & -0.3384 & 1.0506 & -0.0403 & -0.5592 \\
\hline Indirect effect via NT & -0.0526 & -0.0013 & -0.1105 & -0.5175 & -0.2721 & 0.0622 \\
\hline Indirect effect via NGL & -0.0035 & -0.0018 & 0.0132 & -0.0447 & -0.0197 & -0.1335 \\
\hline Indirect effect via IL & -0.1040 & 0.1614 & -0.1734 & -0.0538 & 0.0074 & 0.0457 \\
\hline Indirect effect via SD & -0.2088 & -0.0101 & 0.2744 & 0.0180 & -0.0209 & 0.4533 \\
\hline Indirect effect via LDM & -0.2197 & 0.0261 & 0.2568 & 0.01269 & 0.0997 & 0.0002 \\
\hline Total & 0.6075 & 0.6097 & -0.0778 & 0.4653 & -0.2459 & -0.4676 \\
\hline \multicolumn{7}{|l|}{ SD } \\
\hline Direct effect on SDM & 0.9630 & 0.4681 & 0.6818 & 0.3888 & 0.3935 & 0.6341 \\
\hline Indirect effect via NT & 0.062 & 0.0013 & -0.1344 & -0.0192 & -0.2933 & 0.0119 \\
\hline Indirect effect via NGL & -0.0035 & 0.0018 & -0.0325 & -0.0260 & 0.2841 & -0.0711 \\
\hline Indirect effect via IL & -0.3426 & 0.3457 & -0.4738 & -0.1587 & -0.1444 & 0.1474 \\
\hline Indirect effect via SL & -0.2593 & -0.0077 & -0.1362 & 0.04874 & -0.0043 & -0.3998 \\
\hline Indirect effect via LDM & 0.0643 & -0.0934 & 0.3632 & -0.0078 & 0.1836 & 0.0063 \\
\hline Total & 0.4839 & 0.8127 & 0.2681 & 0.2258 & 0.3686 & 0.7002 \\
\hline \multicolumn{7}{|l|}{ LDM } \\
\hline Direct effect on SDM & -0.3555 & 0.4224 & 0.4572 & -0.1016 & -0.4268 & 0.0335 \\
\hline Indirect effect via NT & -0.0578 & -0.0044 & -0.1046 & 0.1396 & 0.5458 & 0.1771 \\
\hline Indirect effect via NGL & -0.0018 & 0.0025 & -0.0098 & -0.0709 & -0.0161 & 0.0464 \\
\hline Indirect effect via IL & -0.0461 & -0.1780 & -0.2982 & 0.0381 & -0.0177 & 0.0619 \\
\hline Indirect effect via SL & 0.7396 & 0.0223 & -0.1901 & -0.1312 & 0.0094 & -0.0031 \\
\hline Indirect effect via SD & -0.1751 & -0.1035 & 0.5417 & 0.0298 & 0.0153 & 0.1196 \\
\hline Total & 0.1034 & 0.2488 & 0.3962 & -0.0963 & 0.1099 & 0.4555 \\
\hline Coefficient of determination & 0.8653 & 1.0026 & 0.8324 & 0.9124 & 0.8711 & 0.9593 \\
\hline Residual effect & 0.3670 & 0 & 0.4093 & 0.2959 & 0.3589 & 0.2016 \\
\hline
\end{tabular}

NT, number of tillers; NGL, number of green leaves; IL, internode length; SL, stalk length; SD, stalk diameter; LDM, leaf dry matter. *Path analysis with multicollinearity (highest variance inflation factor $=6.11 ; \mathrm{K}$ value $=0.2069$ ).

NT was second in importance, as it had strongly positive, direct effects on SDM at most timepoints $(90,120,150$, and 180 days). This suggests that significant gains in SDM can be obtained through indirect selection for SDM via SD, or SD and NT. These results corroborate those obtained by Kang et al. (1983), who decomposed genotypic correlation 
coefficients and reported a large contribution by SD, followed by the number of stalks, on sugarcane yield per hectare. The authors stated that genotypic path coefficients are important in choosing an effective selection criterion (Kang et al., 1983).

Table 3. Decomposition of genotypic correlations into components of direct and indirect effects involving the main dependent variable (total recoverable sugar, TRS) and independent, technological explanatory variables in 12 sugarcane genotypes at harvest*.

\begin{tabular}{|c|c|c|c|}
\hline Brix & Estimate & RS & Estimate \\
\hline Direct effect on TRS & 0.5172 & Direct effect on TRS & -0.1125 \\
\hline Indirect effect via fiber & -0.0553 & Indirect effect via Brix & -0.4088 \\
\hline Indirect effect via purity & 0.0868 & Indirect effect via fiber & 0.0667 \\
\hline Indirect effect via juice pol & 0.2867 & Indirect effect via purity & -0.1098 \\
\hline Indirect effect via RS & 0.0889 & Indirect effect via juice pol & -0.2977 \\
\hline Indirect effect via t pol ha-1 & 0.0316 & Indirect effect via t pol ha- & -0.0373 \\
\hline Indirect effect via t sugarcane ha $^{-1}$ & -0.0109 & Indirect effect via t sugarcane $\mathrm{ha}^{-1}$ & 0.0158 \\
\hline Total & 0.9742 & Total & -0.8897 \\
\hline Fiber & & t. pol ha-1 & \\
\hline Direct effect on TRS & -0.1078 & Direct effect on TRS & 0.0485 \\
\hline Indirect effect via Brix & 0.2651 & Indirect effect via Brix & 0.3368 \\
\hline Indirect effect via purity & 0.0678 & Indirect effect via fiber & -0.0303 \\
\hline Indirect effect via juice pol & 0.1852 & Indirect effect via purity & 0.0844 \\
\hline Indirect effect via RS & 0.0695 & Indirect effect via juice pol & 0.2343 \\
\hline Indirect effect via t pol ha-1 & 0.0136 & Indirect effect via RS & 0.0864 \\
\hline Indirect effect via t sugarcane ha $^{-1}$ & -0.0039 & Indirect effect via t sugarcane $\mathrm{ha}^{-1}$ & -0.0239 \\
\hline Total & 0.4834 & Total & 0.7388 \\
\hline Purity & & $\mathrm{t}$ sugarcane $\mathrm{ha}^{-1}$ & \\
\hline Direct effect on TRS & 0.1098 & Direct effect on TRS & -0.0283 \\
\hline Indirect effect via Brix & 0.4089 & Indirect effect via Brix & 0.1989 \\
\hline Indirect effect via fiber & -0.0667 & Indirect effect via fiber & -0.0150 \\
\hline Indirect effect via juice pol & 0.2978 & Indirect effect via purity & 0.0613 \\
\hline Indirect effect via RS & 0.1125 & Indirect effect via juice pol & 0.1570 \\
\hline Indirect effect via t pol ha ${ }^{-1}$ & 0.0373 & Indirect effect via RS & 0.0628 \\
\hline Indirect effect via t sugarcane ha $^{-1}$ & -0.0158 & Indirect effect via t pol ha-1 & 0.0410 \\
\hline Total & 0.8900 & Total & 0.4761 \\
\hline \multicolumn{4}{|l|}{ Juice pol } \\
\hline Direct effect on TRS & 0.3094 & Coefficient of determination & 0.9745 \\
\hline Indirect effect via Brix & 0.4793 & Residual effect & 0.1598 \\
\hline Indirect effect via fiber & -0.0645 & $\mathrm{~K}$ value used in the analysis & 0.0056 \\
\hline Indirect effect via purity & 0.1057 & & \\
\hline Indirect effect via RS & 0.1082 & & \\
\hline Indirect effect via t pol ha- & 0.0367 & & \\
\hline Indirect effect via t sugarcane ha $^{-1}$ & -0.0144 & & \\
\hline Total & 0.9778 & & \\
\hline
\end{tabular}

RS, reducing sugar. t, tonne. *Path analysis with multicollinearity (highest variance inflation factor $=14.41 ; \mathrm{K}$ value $=0.005638$ ).

Unlike SD and NT, the other variables did not have strong direct effects of stalk dry matter, at most timepoints, which, in addition to being weak, were mainly negative. According to Cruz et al. (2006), in this situation, the independent trait is not the main determinant of alterations in the main variable; other factors can also have a large impact in terms of genetic gain in selection. Given these biometric data results, we suggest the development of a selection index for sugarcane genotypes using SD and NT.

Interestingly, despite its weak and negative direct effects at most timepoints, IL had a strongly positive indirect effect on SDM via SD at most timepoints (Table 2). Therefore, SD may be used to indirectly select for sugarcane yield. Sugarcane yield is a complex trait that is influenced by several inter-related traits. In this regard, path analysis is an important

Genetics and Molecular Research 16 (1): gmr16019038 
statistical tool in identifying components that have a large effect (Esposito et al., 2012). SD, a variable that is easily measured, was the component that contributed the most to sugarcane yield among the production variables, indicating the possibility of obtaining significant gains through indirect selection for SDM via SD.

As shown in Table 3, strong, positive genotypic correlations were obtained between the technological variables and the main variable (TRS), except for RS (-0.8897). However, only for Brix and juice pol did these significant genotypic correlations result in direct effects (greater than the residual effect) on the TRS. Working with technological variables in sweet sorghum, Lombardi et al. (2015) reported strongly positive direct effects of total Brix per hectare on ethanol production per hectare, and concluded that Brix was the variable that most contributed to ethanol production.

There were positive, indirect effects (greater than the residual effects) of fiber, purity, juice pol, and TPH via Brix on the dependent variable. The exception was the indirect effect of RS via Brix (-0.4088), which was strong but negative. These results confirm the importance of the Brix variable as the main component that increases sugarcane TRS; degrees Brix, followed by juice pol, were the traits that most contributed to TRS. Indirect selection for TRS via Brix, or via Brix and juice pol, could provide significant gains in sugarcane yield.

\section{CONCLUSIONS}

SD contributed the most to sugarcane SDM. Significant gains can be obtained through indirect selection for SDM via SD, or via SD and NT. Of the technological variables, degrees Brix, followed by juice pol, most contributed to sugarcane TRS production. These variables could provide significant gains in sugarcane yield through indirect selection for TRS via Brix, or via Brix and juice pol.

\section{Conflicts of interest}

The authors declare no conflict of interest.

\section{ACKNOWLEDGMENTS}

The authors thank Coordenação de Aperfeiçoamento de Pessoal de Nível Superior (CAPES) and the COMVAP for the financial support to this research

\section{REFERENCES}

Araujo LC, Gravina GA, Marinho CD, Almeida SNC, et al. (2012). Contribution of components of production on snap bean yield. Crop Breed. Appl. Biotechnol. 12: 206-210 http://dx.doi.org/10.1590/S1984-70332012000300007.

Cabral PDS, Soares TCB, Lima ABP, Soares YJB, et al. (2011). Análise de trilha do rendimento de grãos de feijoeiro (Phaseolus vulgaris L.) e seus componentes. Rev. Cienc. Agron 42: 132-138 http://dx.doi.org/10.1590/S1806$\underline{66902011000100017 .}$.

Cruz CD, Regazzi AJ and Carneiro PCS (2006). Modelos biométricos aplicados ao melhoramento genético, 2nd edn. UFV, Viçosa.

Esposito DP, Peternelli LA, Paula TOM and Barbosa MHP (2012). Análise de trilha usando valores fenotípicos e genotípicos para componentes do rendimento na seleção de famílias de cana-de-açúcar. Cienc. Rural 42: 38-44 http:// dx.doi.org/10.1590/S0103-84782011005000152.

Falconer DS and Mackay TFC (1996). Introduction to quantitative genetics, 4th edn. Longmans Green, Harlow, Essex, UK.

Genetics and Molecular Research 16 (1): gmr16019038 
Faria LA, Pelúzio JM, Afférri FS, Carvalho EV, et al. (2015). Path analysis for growth and grain yield of corn genotypes under different nitrogen doses. J. Bioenergy Food Sci 2: 1-11 10.18067/jbfs.v2i1.13.

Farias FJC, Carvalho LP, Silva Filho JL and Teodoro PE (2016). Correlations and path analysis among agronomic and technological traits of upland cotton. Genet. Mol. Res. 15: 1-7 http://dx.doi.org/10.4238/gmr.15038239.

Ferreira FM, Barros WS, Silva FL, Barbosa MHP, et al. (2007). Relações fenotípicas e genotípicas entre componentes de produção de cana-de-açúcar. Bragantia 66: 605-610 http://dx.doi.org/10.1590/S0006-87052007000400010.

Hoogerheide ESS, Vencovsky R, Farias FJC, Freire ECE, et al. (2007). Correlações e análise de trilha de caracteres tecnológicos e a produtividade de fibras de algodão. Pesq. Agr. Bras 42: 1401-1405 http://dx.doi.org/10.1590/S0100204X2007001000005.

Kang MSMS, Miller JD and Tai PYP (1983). Genetic and phenotypic path analysis and hereditability in sugarcane. Crop Sci. 23: 643-647. http://dx.doi.org/10.2135/cropsci1983.0011183X002300040010x

Kavalco SAF, Figueiredo R, Groli EL, Zimmer CM, et al. (2014). Análise de trilha em genótipos de trigo submetidos ao estresse por encharcamento. Semina: Cienc. Agrar. 35: 1683-1696 http://dx.doi.org/10.5433/1679$0359.2014 \mathrm{v} 35 \mathrm{n} 4 \mathrm{p} 1683$.

Li CC (1956). Concept of path coefficient and its impact on population genetics. Biometrics 12: 190-210. http://dx.doi. org $/ 10.2307 / 3001760$

Li CC (1975). Path analysis: a primer. Boxwood Press, Pacific Grove, CA, USA.

Lombardi GM, Nunes JA, Parrella RA, Teixeira DH, et al. (2015). Path analysis of agro-industrial traits in sweet sorghum. Genet. Mol. Res. 14: 16392-16402 http://dx.doi.org/10.4238/2015.December.9.8.

Marchezan E, Martin TN, Santos FM and Camargo ER (2005). Análise de coeficiente de trilha para os componentes de produção em arroz. Cienc. Rural 35: 1027-1033. http://dx.doi.org/10.1590/S0103-84782005000500007

Montgomery DC and Peck EA (1981). Introduction to linear regression analysis. John Wiley, New York.

Moura JO, Rocha MM, Gomes RLF, Freire Filho FR, et al. (2012). Path analysis of iron and zinc contents and others traits in cowpea. Crop Breed. Appl. Biotechnol. 12: 245-252 http://dx.doi.org/10.1590/S1984-70332012000400003.

Peter FA, Alcântara Neto F, Barros WS, Almeida FA, et al. (2014). Phenotypic correlations and path analysis of soybean production components in the Brazilian cerrado of Piauí state. Rev. Cienc. Agr 57: 273-279 10.4322/rca.ao1412.

Reddy CR and Reddy MV (1986). Degree of genetic determination, correlations and genotypic and phenotypic path analysis of cane and sugar yield in sugarcane. Indian J. Genet. Plant Breed. 46: 550-557.

Santos A, Ceccon G, Davide LMC, Correa AM, et al. (2014). Correlations and path analysis of yield components in cowpea. Crop Breed. Appl. Biotechnol. 14: 82-87 http://dx.doi.org/10.1590/1984-70332014v14n2a15.

Silva FL, Pedrozo CA, Barbosa MHP, Resende MDV, et al. (2009). Análise de trilha para os componentes de produção de cana-de-açúcar via Blup. Rev. Ceres 56: 308-314.

Souza ERA, Oliveira FJ, Anunciação Filho CJ, Melo Filho PMA, et al. (2011). Seleção de famílias RB visando à alta produtividade e precocidade na maturação em cana-de-açúcar. Bragantia 70: 788-795 10.1590/S000687052011000400009.

Sukhchain SD and Sain GS (1997). Inter-relationships among cane yield and commercial cane sugar and their component traits in autumn plant crop of sugarcane. Euphytica 95: 109-114 http://dx.doi.org/10.1023/A:1002962131707.

Thornthwaite CW and Mather JR (1955). The water balance. In: Climatology. Drexel Institute of Technology, Centerton. Wright S (1921). Correlation and causation. J. Agric. Res. 20: 577-585.

Wright S (1923). Theory of path coefficients. Genetics 8: 239-255.

Genetics and Molecular Research 16 (1): gmr16019038 